\title{
Small Congenital Melanocytic Nevus
}

National Cancer Institute

\section{Source}

National Cancer Institute. Small Congenital Melanocytic Nevus. NCI Thesaurus. Code C66754.

A cong enital nevus of small size, with a diameter smaller than $1.5 \mathrm{~cm}$. It presents as a macular, papular or plaque-like lesion. 